\title{
Tables, Figures, and Maps
}

Tables

2.1 Principal U.S. Petroleum Products (2005) 19

2.2 U.S. Petroleum Consumption by End-Use Sector 21

2.3 Share of Energy from Petroleum by End-Use Sector 21

3.1 Projections of World Oil Consumption (June 2006) 35

3.2 Major Oil Supply Disruptions Since 1973

3.3 Factors Influencing the Economic Costs of Future Oil Shocks 47

3.4 Leading Net Petroleum Exporters, 2003

4.1 Prices for Crude Oil and Gasoline, 1968-1982 80

4.2 Comparison of Oil Consumption in $2005 \quad 95$

6.1 Estimates of Annual Military Expenditures for

Defending Middle East Oil Supplies 157

6.2 Forces Assigned to CENTCOM for Planning Purposes or

Used in Major Persian Gulf Military Operations $\quad 170$

6.3 Annual Cost of U.S.-Based General Purpose Forces and

Strategic Lift Attributable to Persian Gulf Missions 174

8.1 Benefits and Costs of U.S. Foreign Oil Dependence 206 


\section{Figures}

2.1 U.S. Energy Consumption, 1949-2005 17

2.2 Shares of U.S. Energy Consumption by Fuel, 1949-2005 18

2.3 U.S. Petroleum Consumption, 1949-2005 20

2.4 U.S. Petroleum Consumption, Production, and Imports, 1949-2005 24

2.5 Imports as Share of U.S. Oil Consumption, 1949-2005 26

3.1 Cost of Net U.S. Petroleum Imports, 1974-2005 31

3.2 Crude Oil Spot Prices and Futures, 2002-2006 38

3.3 Distribution of World Oil Production, 1965-2005 49

3.4 OPEC Spare Production Capacity, 1970-2005 55

3.5 U.S. Petroleum Stocks, 1977-2005 57

4.1 Nominal and Real Value of Federal Excise Tax on Gasoline, 1970-2005 65

4.2 Passenger Car Fuel Economy, 1973-2005 69

4.3 Light-Duty Vehicle Market Shares, 1975-2005 72

4.4 Federal Energy Research and Development, 1972-2003 77

4.5 OECD Oil Stocks, 1973-2005 90

5.1 Persian Gulf Shares of World Oil Production, Exports, and

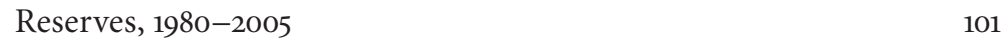

5.2 Persian Gulf Oil Production, 1965-2005 104

5.3 Latin American Oil Exports, 1965-2005 131

5.4 Sub-Saharan African Oil Production, 1975-2005 145

Maps

5.1 Persian Gulf 99

5.2 Caspian Sea Region 135

5.3 Gulf of Guinea 144 